MINES AND PETROLEUM BULLLETIN

October 1968

Vol. XVI

No. 10

\title{
REORGANIZATION OF DIVISION
}

The Division of: Mines and Minerals has been divided into two Divisions, each with a new name. - The Fetroleum Branch of the old Division of Mines and Minerals is now the Division of Oil and Gas. If remains at 3001 Porcupine Drive, Anchorage, and the phone number remains 279-1433. A Director will be named soon. Oil and gas news will continue to be reported in this Bullefin until other arrongernents are made.

The name of the original Division has been changed to the Division of Mines and Geology to more accurciely, reflect its work and to designate it as the official State geological ogency. It now consists of four Brancties:. Administration, Mining, Laboratory, and Geology. James A. Williams remains ine Director, and the Division location is at College (phone 479-2202) as per the above heading axcepf for" its two Mining. "information Offices. The Anchorage Mining Information Office remains at 3001 Porcupine Drive and the phone number is 279-2814. The Juneau Mining Information Office is in the Goldstein Building at Department headquarters. The mailing address there is Pouch $M$, Juneau, and the phone number is 586-6351.

Thomas. E. Kelly, Commissioner of the Department of Natural Resources, stated that the change was made to upgrade the Petroleum Branch to meet the "obvious need of placing greater emphasis on control and effective regulation of oil and gas production to protect the State's interest." It is understood that the oil and gas leasing function of the Division of Lands may be added to the Division of Oil and Gas sometime in the future. The reorganization now places four Divisions under the Department of Natural Resources: Agriculture, Lands, Mines and Geology, and. Oil and Gos...;

\section{DMG QUARTERS DEDICATED}

The office and laboratory quarters of the Division of Mines and Geology on the campus of the University of Aloska were the scene of a dedication ceremony and open house on the afternoon of Saturday, October 5. Speakers for the occasion were Governor Wolter J. Hickel, University President William R. Woud, Commissioner of Natural Resources Thomas E. Kelly, University Board of Regents President Elmer E. Rasmuson, Alaska Miners Association (Fairbanks Branch) Chairman Denny $G$. Breaid, Kennecott Copper Corp. representative Charles T. Penney, and Division Director James $A$. Willians. Earl H. Beistline, Denn. of the University Colloge of Earth Sciences ard Mineral Industry, was Master of Ceremonies. A goodly crowd turned out.

Governor Hickel's address included the following: "This is a very minimum start. It was a difficult decision to make it happen. What we are in here today is an idea that has just been borm. would like to see a mines and minerals complex here second to none. There is not a spor on earth with such great potential, yei where so little has been done to explore and search out the riches as here in Alaska. It is appalling to allow this lack of interest. In the areas of government that: compete with the free world, they are for ahead of us in real minerad woolth. As sure as.l am 
standing here, one of the things Kruschev meant when he said he would bury us and what Russia is doing, is economics. What we are going to try to do here for the United States and the free world is try to bring us up in the next ten years to where we should have been twenty years agos. There is great opportunity here in this Pacific bosin. Federal, State and University have to get together behind one idea and in one spot to heve a Mines and Minerais building and facilities that can really do all the things we have talked about, and take advantage of what has been given us. That is a real futuro."

Commissioner Kelly said: "We are most honored here today to go through this facility. It is a combination of quite a few years' effart. Governor Hickel wisely saw this quite a few yecrs ago-the idea to hove the State Division of Mines and Minerals to work with the University in cooperation-in materials and idecs. For the development of exploration work in hardrock mining. Toward this end: he worked to transfer this. Division from Juneau to Fairbanks. This is fust a start. It is our hope that a large industry building incorporating Federal, State and University mineral organizations will be housed in one facility. It will be a good thing for al! Alcska becouse vie have such tremendous mineral potential. This will allow the sharing of ideas to fuither the advancement in this aspect of science.".

Following the brief addresses, a four of the offices and laboratory was held for alf those interested. The entire staff was on hand to display aur facilities and equipment and es:plain how our work is done and why it is important to the development of the State's mineral resources. Favorable comments were heand from those attending. If we missed anyone with our moiled invitations sent out in advance who might have ottended," we apologize to them."

\section{NATIVE RESERVATION MINING PROPOSAL'}

Two officials of the U,S.' Bureau of Indian Affairs recently talked with varlous mining authorities throughout Alaska on preliminary planis for opening ceriain Native reservations for mining. They were David. Jones, Valüation Ëngineer, of Washington and Chirles H. Jones, Realty Officer, of Juneau. The twa ME. Jones (no relation) explained that prospecting permits and leases on Indian reservations in the South 48 have been vory successful and thä Alaskan reservations stiould be made available for development without further dalay.

Possibilities under discussion include one-year nonexclusive prospecting permits to be effective in 1969, followed by competitive bidding for exclusive prospecting permits with options to lease. The exclusive prospecting permits would be of longer duration - perhaps five years - and would probably. be renewable at least once. Bidding would be on one or a combination of straight bonuses; rentats, royalties, or work to be perfomed. Tracts would be large -- up to 100,000 acres or more. Reservations being considered for opening include Akutan, Annette Island, Diomede Island, Karluk; Klükwan (parts not already under lease), Unalakleet, Venetie-Chandalar, and Wales.

Final plans are expected to be announced by the B.I.A. by January, 1969:- Fur further information, contact Mr. Dovid Jones, Valuation Engineer, U.S. Department of Interior, Bureau of Indian Affairs, 1951. Constitution Avenue, N.W., Washington, D.C. 20242.

\section{NEW DIVISION PUBLICATIONS}

The Division of Mines and Geology has released four repoirts as lisfod and described below. They are available from our College office by mail and "over the counter" at our Mining Information Offices at Anchorage and Juneau as well as at the College office." The price is $\$ 1.00$ eachi. 
Geochemicat Report No. 16, A Geochemical Investigation of a Portion of the Fortymile District, Alaska: The area covered includes the drainage of Chicken, Lost Chicken, Franklin, Ingle, Wall Street; Fortyfive Pup and Bückskin Ciejeks, portions of iMosquito and South Forks of the Fortymile Rivert, and 'etight other unnamed adjacent creeks. A total of 176 stream sediment samples were taken, of which 25 tód probuble or possible anomalous concentrations of copper, zinc, lead, molybdenum, or nickel". "Limited bedrock sampling, including possibly mineralized vêins," were undertaken, and 26 samples were selected for asecy or analysis. A computation of results from both sources reveal three areas worthy of more detailes investigation. The report contains four pages of text, three tábtes of sample and rock analyses, and a geochemical map. The author is William H. Smith, Geology Field Assistunt of the Division.

Geochemical Report No. 17, A Geochemical Investigation of the Wood River-Tikchik Lakes Area, Southwestern Alaska. The area examined includes the perimeters of the four major lakes of the Wood River Lake system and one of the six lakes in the Tikchik Loke system. The party collected 372 stream sediment samples in the: area. The results indicate that mercury analysis is a good goochemical tool for prospecting in the region. Zinc appoared to be the best indicator of the heavy metals group. Geochenical anpmalies and other field evidence indicated the most favorable locations for exploration are the following: (f) Marsh Mounfain, (2) the south side of the southeast end of Lake Aleknagik, (3) the ridge, on the south side of Sunshine Valley, and (4) the ridge on the south side of Little Togiak Lake. The report confains 18 pages of text, two tables of sample and rock analyses, and three maps. The author is Gilbert R. Eakins, Mining Geologist of the Division.

Geologic Report No. 26, Geological and Geochemical Invéstigations Southwest of Farewell, Alaska. This report covers about 100 square miles of an upland block bounded along the noth edge by the Farewell fault. Recurrent movements along this great break probably have had a strong influence on the emplacement of igneous rocks in the area. A swarm of steep, west-trending, mofic to acidic dikes extends eastward for a distance exceeding five miles from the large granitoid stock at the head of the Middle Fork of the Kuskokwim. "Stream sediments contain scattered nickel, copper, molybdenum, and zinc anornalies, in the upper Middle Fork drainage. These are associated with diabase dikes and/or black slate within and marginal to the silicified aureole around the large granitoid stock at the head of the Middle Fork. One small nickel-bearing pyrrhotite deposit is associated with diabase in this area. The report consists of 10 pages of text, a geological-geochemical mop of the area, and a geologic-geochemical tabulation of sompling results and rock analyses. The author is Gordon Herreid, Mining Geologist of the Division.

Geologic Report No. 29, Progress Report on the Geology and Geochemistry of the Sinuk Area, Seward Peninsula, Aloska. This report and Division of Mines and Minerals Geologic Report No. 24, released in Moy 1966, describe investigations in the Sinuk district made by the author during 1.965 and 1966. Several mineralized localities, indicated by numerous gossans and geochemical anomalies make up the district. Geochemical onomalies found during the 1965 field season at the Quarry and Galena prospects, the Monarch gossan, and elsewhere have bepn seported (Herreidy 1966 t. A geochemical anomaly discovered in 1966 on Aurora Creek is herein reported. The geglogy, os mapped fo date is shown as well as all of the geochemical data and several new assay. The report consists of two pages, one map, and three geologic-geochemical tabulations of sampling results and rock analyses. The author is Gordon Herreid, Mining Geologist of the, Division.

\section{NEW USGS PUBLICATIONS}

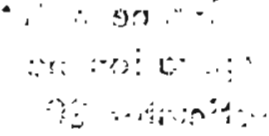

The following circular has recently been released by the USGS and may be obtained free at the various USGS and Division of Mines and Geology offices. 
Circular 593, "Distribution of gold and some base metals in the Slana areo, Eastern Alaska Range, Aloska" by Donald E. Richter and Neal A. Matson, Jr. This report, in which the State Division of Mines and Geology cooperated, points out that in the Slane area, covering about 240 square miles on the south flank of the eastern part of the Alaska Range, trace amounts of gold and base mefals, detected in samples of stream sediments and igneous couniry rocks, show patterns of distribution thaf moy serve as elues to hidden deposits. These patterns, shown in a series of maps, serve to outline favorable target areas believed worthy of exploration by private, interests.

The following open file reports have been released by the USGS and are available for consultation in the Alaskan USGS and State Division of Mines and Geology offices. Material from which copies of these open file reports can be made of private expense is ovailable in the Alaska Geology. Branch, USGS, 345 Middlefield Road, Menlo Park, California 94025.

1. Metallic mineral resources map of the Skagwoy quadrangle, Alaska, compiled by Edward $H$. Cobb. 3 . p. . I map, 1 index map.

2. Metallic mineral resources map of the Mount Fairweather quadrangle, Alaska, compiled by Edword $H$. Cobb. 6 p., 1 map, 1 index map.

3. Metallic mineral resources map of the Junequ quadrangle, Aloska, complled by Edword H. Cobb. 7 p., 1 map, 1 index mop.

4. Motallie mineral resources map af the Sitka quadrangle, Alaska, compiled by Edward. H. Cobb. 5 p., I map, 1 index map.

5. Metallic mineral resources map of the Sumduri quadrangle, Aloska, compilad by Edward $H$. Cobb. 2 p., 1 map, 1 index map.

6. Metallic mineral resources mop of the Port Alexander quadrangle, Alaska, compiled by Edward H. Cobb.: 2 p., 1 map, 1 . index map.

7. Metallic mineral resources map of the Petersburg quadrangle, Aloska, compiled by Edward $\mathrm{H}$, Cobb. 3 p., 1 map, 1 index mop.

8. Metallic mineral resources map of the Brodfield Canal quadrangle, Alaska, compiled by Edward H. Cobb. 3 p., 1 map, 1 index map.

9. Metallic mineral resources map of the Craig quadrangle, Alaska, compilod by Edword H. Cobb. 8 p., 1 mop, $r$ index map.

10: $\therefore$ Metallic mineral resources map of the Ketchikan quadrangle, Alaska, compiled by Edward $H$. Cobb. 4 p., 1 mop, 1 index map.

11. Metallic mineral resources map of the Dixon Entrance quadrangle, Alaska, compiled by Edward H. Cobb. 2 p., 1 map, 1 index map.

\section{MINING NEWS}

Recent nows relecoses include the following items:

Kendrick Boy Mining $C_{0}$. has announced the signing of a joint venture agreement with Newmont Mining Corp. The agreement provides for the further development of the Kendrick Boy uranium. holdings at Bokan Mountain on Prince of Wales Island with Newmont Exploration, Lid. as the operator.

The new 100-tone mill of Chandalar Gold Mining and Milling Co. should be comploted shortly and ready for operation next spring. Frank Birch, owner, and operator of Chandalar Gold Mining and Milling, estimates 20 years of ore in sight with a warth of $\$ 5$ million. The district is 200 miles north of Fairbanks, above the Arctic Circle. 
Construction of a new- highway bridge across the Copper River at Chitina--which will open. up hundreds of miless of prime mining and recreation country, has been scheduled for a definite start next spring. Cosby . Steen, State Commissioner of highwoys; soid that bids will also be called for this winter for further reconstruction work on the road from Chitina north. : Lack; of : a bridge at Chitina is the main bottleneck to connecting up nearly a hundred miles of roodway along the route of the old Copper. River and. Northwestern Roilroad from Chitino into McCarthy and Kennecott and out to vorious arooks in that orea. The now highwoy link is expected to be: a spur for possible growth of copper mining activity in the area. There are several small mining companies presently active there developing prospects, but it is not feasible to go into production until a road is available for hauling out the mined ore.

The White Pass \& Yukon: Railway's new ore shipping terminal at Skagway is coming along on schedule. A $\$ 1.3$ million. first phase project, includes dredging of a boot basin using the idradged material to provide the base for the foundation for the new terminal. The $\$ 3.3$ million second phase, to get underwoy soon, will include mooring facilities for buik carriers, a storage stied. With capacity for 75,000 tons of concèntrates, and a conveyor loading system including:a:72-foot-high fixed position loading tower. . Slated for completion by August 31, 1969, the system will have an orinual capacity of 450,000 tons; iof lead-zinc : concantratia and 50,000 tons of copper concentrate: Ship's will be loaded at a rate of 1,000 tons per hour. Most of the tonnage is expected to come from Anvil's new lead-zinc mine near Ross River, 120 miles northeast of Whitehozse; it is schedule to go into production next fallt: Other smaller mines in the Yukon also will be shipping via the White Pass \& Yukon.

\section{VITRO MINERALS CHANGE}

Earth Resources Company has acquired Vitro Minerals Corporation, a subsidiary of Vitro Corporation of America, Dan M! Kfaussa, Earth Resouices President, recently announced: Earth Resources is a new company; organizeditin duly io explore for minerals, primarily strategic metals. Vitiso Minerals has been in business sines 1955 as a subsidiary of Vitro Corporation of America, and exploration heodquarters are now located in Salt Loke City, Usah. It is active in exploration for precious, base and strategic metals; and is the operator of a joint venture with Marathon Qil Company for uranium exploration in the United States.

A principal income-producing property of Vitro Minerals is the Cripple Creek coal mine near Healy, Alaska, in the Nenana coal field. There will be no change in the present management of Vitro Minerals Corpotion: and:Mr: C. E. Me.Guire of Fairbanks will continue to in charge of the Cripple Creek mine: it'is conjectured that the change may make Vitro's postponed Alaskan exploration program a mòre immediate possibility:

OIL AND GAS NEWS

(Prepared by the Division of Oil and Gas)

Nine applications for drilling permits were approved by the Division of Oil and Gos as follows:

ReminitNo. 68-76. Union Oil Company of:California "A-18 Trading Boy State,

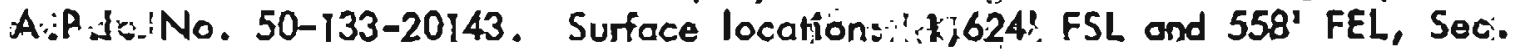

4; F9N, RI3W, S.M. Bottom hole locotioni: 350! FNL and 550' FWL, Sec. 3, T9N, Ri3W, S.M. This is a development focation in the Trading Bay Field. 
Permit No. 68-77. Standard Oil Company of California; W.O.1: \$4-8

Moquawkie, A.P.1. No. 50-283-20117, 660' FSL and 660! FEL, Sec. 8, T11N,

RIIW, S.M. This exploratory location. is about two miles southeast of the

Moquawkie Gas Field.

Permit No. 68-78. Marathon Oil Company " Clam Gulch, A.P.1. No. 50-133-20144. $1,980^{\circ} \mathrm{FSL}$ and $660^{\circ} \mathrm{FWL}$, Sec. 3, TIN, RI3W, S.M. This exploratory location is about 25 miles southwest of Kenai, Alaska.

Permit No. 68-79. Shell Oil Company "C-11-26. Middle Ground Shoal, A.P.1. No. 50-133-20145. Surface location: 501' FSL and 1,542'FEL, Sec. 23, T8N, R13W, S.M. Bottom hole location: 1,030' FNL and 940' FWL', Sec. 26, T8N, RI3W, S:M. This development location is in the Middle Ground Shoal Field.

Permit No. 68-80. Union Oil Compony of Californio "G-14 Trading Bay Unit; A.P.I. No. 50-133-20146. Surface location: 1,876' FSL and 1,378' FEL, Sec. 29, TSN, R13W, S.M. Bottom hole location: $20^{\prime}$ FSL and 1,380' FWL, Sec. 34, TSN, RI3W, S.M. This development location is in the McArthur River Field.

Permit No. 68-81. Pan American Petroleum Corporation 1 USA Big Lake, A.P.I. No. 50-009-20001. 1,980' FSL and 1,980 FWL, Sec. 1, T15N, R4W, S.M. This exploratory location is about 25 miles north of Anchorage, Alaska.

Permit No. 68-82. Union Oil Company of California "D-6 Trading Bay Unit, A.P.1. No. 50-133-20147. Surface location: 673' FSL and 1,220' FWL, Sec. $6,{ }^{\prime}$ T8N, RI3W, S.M. Bottom hole location: 2,200' FNL and 40' FEL, Sec. 8, TRN, RI3W, S.M. This development location is in the MCArshur River Field.

Permit No. 68-83. Union Oil Company of California K-11 Trading Boy Unit, A.P.1.' No. 50-133-20148. Surface location: 617 FSL and 131' FEL, Sec. 17, T9N, Ri3W, S.M. Bottom hole location: 2,200' FNL and 2,090' FEL, Sec. 20, T9N, R13W, S.M. This development locotion is in the McArthur River Field.

Permit No.' 68-84. Pan Ämerican Petroleum Corporation "1 USA Pan Americion David River, A.P.1. No. 50-211-20001. 1,650' FSL and 1,650' FWL, Sec. 12, T50S;, R8OW, S.M. This explorctiory location is about 50 miles northeast of Cold Bay, Alaska.

DRILLING ACTIVITY (as of September 27, 1968)

Operator

Atlantic Richfield Co.

B. P. Exploration U.5.A., Inc.

Marathon Oil Corp.

Mesa Perroleum Co.

Mobil Oil Corp.

Mobil Oil Corp.
Well Names \& Numbers

Sag River State 1

Sag Delta 1

Clom Gulch 1

Kasilof. Unit \#2

Granite Point State "44-11

Granite Point State $42-23$
Type $\cdot \underline{\text { Status }}$

E

E

E

E

$D$

D
Drilling Location Location Location Drilling Drilling 


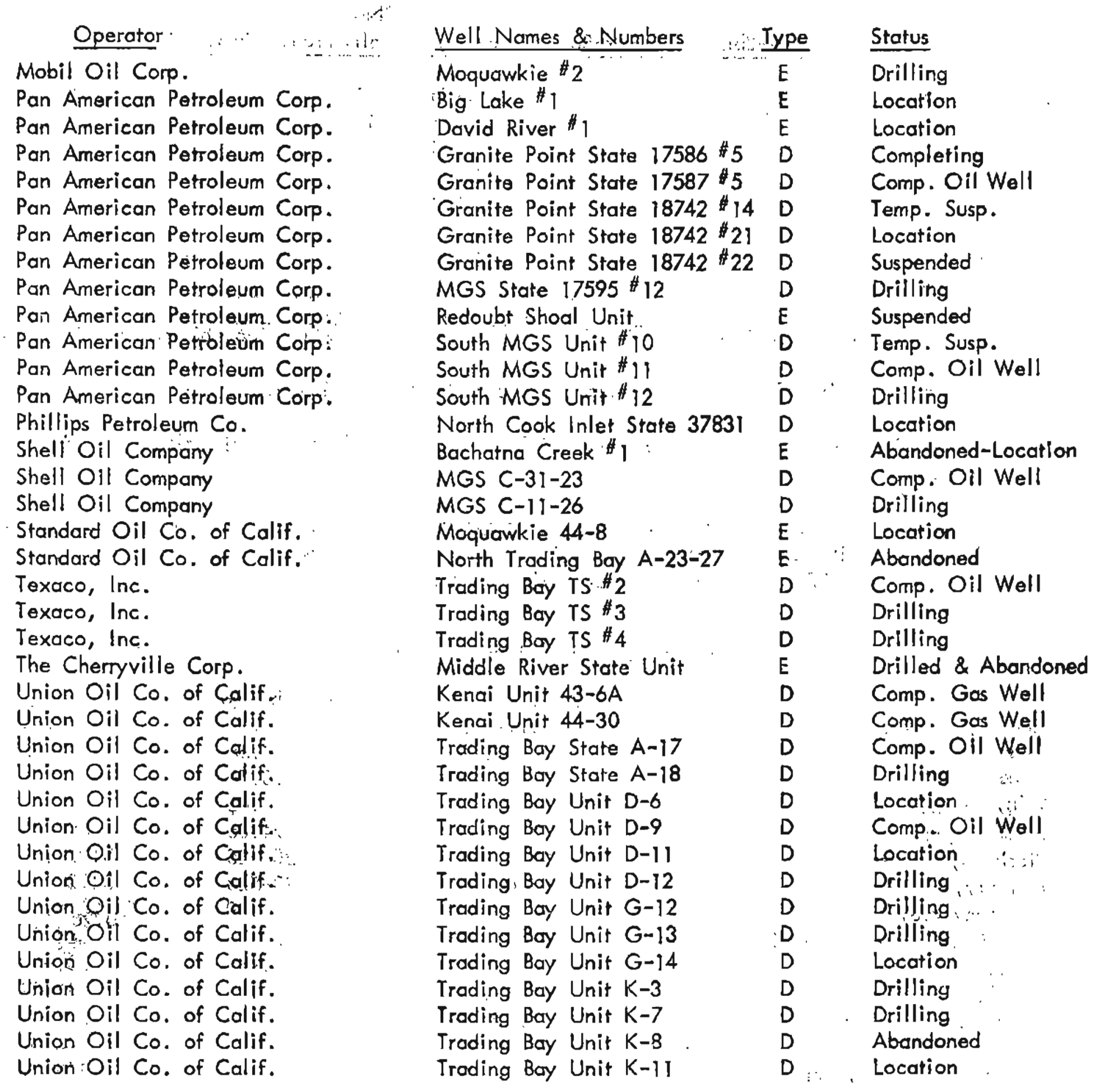

"E" indicates an exploratory well, and "D" a development well.

PRODUCTIQN - August 1968 (Gas pressure bose 14.65 psii). *No: of

\begin{tabular}{|c|c|c|c|c|c|c|}
\hline Field & Oil-Bbls & Water-Bbls & Gas-MCF & Wells Prod. & Cum. Oil. & Cum. Gas \\
\hline Granite Poir & 989 & 12,520 & 639,302 & $31(3)$ & $16,900,381$ & 2,$079 ; 654$ \\
\hline McArthur River & $2,366,778$ & $* 33,175$ & $\star * 652,158$ & 22 & $13,602,316$ & $3,770,192$ \\
\hline Middle Ground Shoal & $1,263,717$ & 43,545 & 531,802 & $46 !$ & $19,801,077$ & $9,008,116$ \\
\hline Swanson River & 1,060 & 192,183 & $1,950,475$ & 421 & 2,698 & 555 \\
\hline $\begin{array}{l}\text { Trading Boy } \\
\text { Total }\end{array}$ & $\frac{327,472}{6,007,534}$ & $\frac{2,912}{284,335}$ & $\frac{272,811}{4,046,548}$ & $\frac{15(3)}{156(16)}$ & $\frac{2,581,033}{136,887,505}$ & $\frac{2,342,079}{75,799,756}$ \\
\hline
\end{tabular}


No. of

Beluga River

Kenai

Kenoi Deep

Moquowikie

Sterling

South Barrow

Trading Bơy

Inactive Gos Fields

Total Dry Gos:

STATE GRAND TOTAL

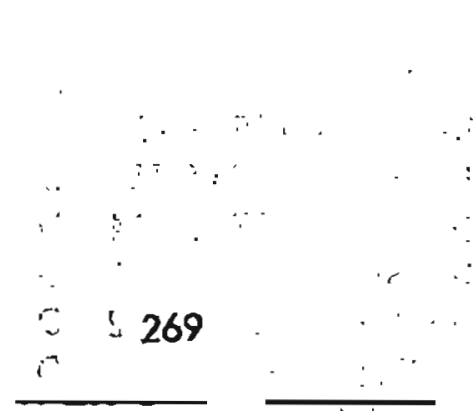

166,176

3,$513 ; 3111$

295,774

$25,7.56$

10,134

30,277

23,622

Wells Prod.

Cum. Oil

Cum. Gos

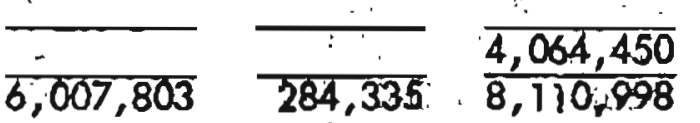

$1,079,599$

$115,036,475$

$1,500,623$

i] 13,869

426,737

$3,72,779$

166,683

Average penday: Oil, 193,800; Csg. Head, 130,534; Dry Gas, 131;111;-Total-Gas, 261,645.

*Dual completions are included as two wells; triple, as. three. (_) Number of wells not producing in August.

**Water and gas figures were reversed in July. Should have read: Wotar, 19,990; Gas, 633,488. Total water for oil fields and State, 263,794: Total cosinghead gos, 4,819,464; and total gas for State, $8,714,417$. No change in cumulative totals.

\section{E. AND M.J. METALL MARKET PRICES}

Copper, per lib.

Lead, per lb.

Zinc, per $1 b$.

Tin, per lb:

Nickel, per lb:

Platinum, per oz.

Mercury, per flask

Antimony ore, per unit*

Beryllium powder, 98\% (Ib)

Chrome ore, long ton

Molybdenum conc, per It.

Titanium oie, per ton

Tungsten, per unit

Silver, New York, per oz.

Gold, Engelhard, per oz. $\frac{\text { September }}{41.722 \hat{2}}$

$12.5 \mathrm{c}$

13.5

$152: 0 c$

94.06

$\$ 120-125$

$\$ 550-555$

$\$ 5.80$

$\$ 54-66$

$\$ 31-35$

$\$ 1.62$

$\$ 20-21$

$\$ 43,00$

$218.0 \mathrm{c}$

$\$ 40.20$
Month Ago

4).7द

12.56

13.54

$142.0<$

94.0

$\$ 120-125$

$\$ 523-528$

$\$ 5: 80$

$\$ 54-66$

$\$ 37-35$

$\$ 162$

$\$ 20-21$

$\$ 43: 00$

$219.5 \mathrm{c}$

$\$ 39.02$ $\frac{\text { Year Ago }}{39.1 t}$

$14 c$

14

$151.9 \mathrm{c}$

$85.25 \%$

$\$ 109-112$

$\$ 490-495$

$\$ 5.26-6.20$

$\$ 54-66$

$\$ 31-35$

$\$ 1 \vdots 62$

$\$ 21-24$

$\$ 43.00$

$169.5 \mathrm{c}$

*Prices quated for September 30 and month ago are for New York, lump, siv, 60\%; price quisted for year ago is for New York, lunipr, stu, 50\%. Apparently $50 \%$ antimony is no longer being quoted riby E. and M.J.r.
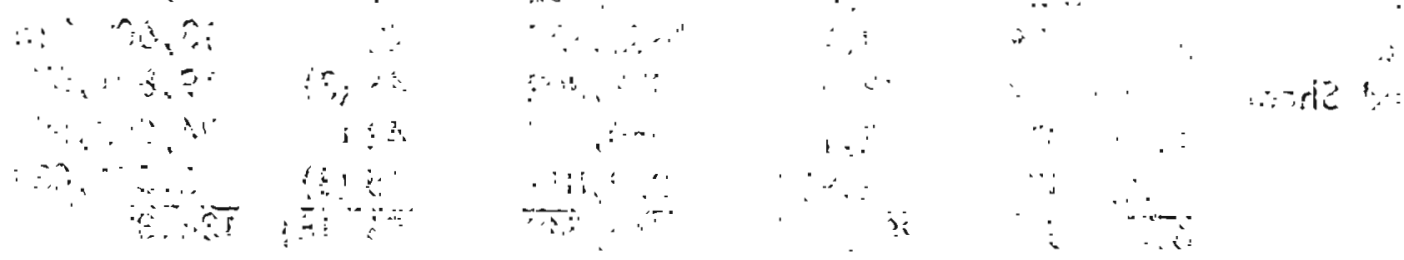